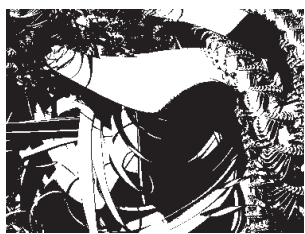

\title{
DOŽIVLJAJ I PRAKSA RODITELJSTVA U RAZLIČITIM ŽIVOTNIM RAZDOBLJIMA
}

Katica LACKOVIĆ-GRGIN

Zadar

UDK: 159.947 .5

316.628

316.356 .2

Pregledni rad

Primlieno: 10. 5. 2010.

Na motivaciju za roditeljstvo, odnosno na potrebu, želju i odluku za dobivanje djece, utječu biološki, psihološki i socijalni faktori. O njihovoj interakciji ovisi preuzimanje i prihvaćanje roditeliske uloge i kvaliteta odnosa s djecom u različitim razdobljima života. Namjera ovoga rada jest raspraviti neke posebnosti roditeljstva s obzirom na razvojne značajke roditelja i djece. U adolescenciji doživljaj i praksa roditeljstva razlikuju se od onih u odrasloj dobi. Mladima nedostaju mnogi resursi koji omogućuju istaknutost roditeljske uloge i roditeljsku predanost. U mlađoj odrasloi dobi socijalna mreža ohrabruje roditeljstvo, što pridonosi porastu značenja majčinskoga, odnosno očinskog, identiteta, koji utječe na doživljaj roditeljstva i na otvorene oblike roditeljskoga ponašanja. Doživljaj i praksa roditeljstva u zreloj odrasloj dobi povezani su s razvojem generativnosti, pa odnosi odraslih roditelia i njihove djece postaju kompleksniji. U odnosu s djecom pojavljuje se ambivalencija, posebice kad djeca nisu postigla predviđeni normativni status (završetak obrazovanja, financijisku neovisnost, sklapanje braka i dr.). U starosti, koja je posvećena rješavanju krize integriteta nasuprot očaju, aktualni doživljaj roditelistva povezan je s evaluacijom njegovih značajki tijekom ranijih razdoblja života. Ishodi te evaluacije, jednako kao i kvaliteta aktualnih odnosa, određuju ponašanja prema odrasloj djeci te zadovoljstvo roditeljstvom.

Ključne riječi: faze roditeljstva, motivacija za roditeljstvo, roditeljsko ponašanje, roditeljski identitet, generativnost, ekstenzija roditelistva 
Između brojnih socijalnih uloga u životu većine ljudi najistaknutije mjesto zauzimaju obiteljske i profesionalne uloge. Od svih obiteljskih uloga roditeljska je najvažnija i s individualnoga i s društvenoga stajališta.

Roditeljstvo je kompleksan pojam koji uključuje odrednice kao što su: motivacija za dobivanje djece, preuzimanje i prihvaćanje odgovornosti i brige za njihovu dobrobit, kao i vrijednosti i ciljevi koji se u roditeljskoj ulozi mogu realizirati. Vrijednosti i ciljevi roditelja individualno su različiti, ali su, prema rezultatima nekih međukulturnih istraživanja, u svim kulturama zastupljene praktične i ekonomske vrijednosti roditeljstva, kao i psihološke vrijednosti, među kojima se ističu: emocionalna povezanost s djecom te osjećaj ispunjenosti i privrženosti (Hoffman, 1987.).

Doživljaj roditeljstva ovisi o spolu i dobi roditelja i djece, o kvaliteti partnerskih odnosa, ali i o konkretnoj društvenoj atmosferi, odnosno o povijesnom vremenu. $U$ vezi s tim varirao je i odnos prema djeci - od poticanog i prakticiranog infanticida u grčkoj Sparti ili u nekim današnjim plemenima u Indiji preko filozofije mortaliteta (izraženog u Mussolinijevoj doktrini da u kući treba biti dovoljno djece i čaša, jer kad se razbije jedna ostat će druge), do suvremeno propagiranih i prakticiranih odnosa ljubavi, brige i podrške što ih roditelji pružaju svojoj djeci u procesu njihova odrastanja. Suvremena istraživanja pokušavaju utvrditi koliko doživljaj roditeljstva ovisi o ličnosti roditelja (Prinzie i sur., 2009.), o dječjem temperamentu (Kochanska, 2001.) i o profesionalnoj angažiranosti roditelja (Grzywacz i Marks, 2000.).

Na motivaciju za roditeljstvo, odnosno na potrebu, želju i odluku za dobivanje djece, utječu biološki, psihološki i socijalni čimbenici. Naše istraživanje (Lacković-Grgin i Vitez, 1997.), potvrdilo je postojanje četiriju kategorija motivacije, koje je ranije identificirao Rabin (1965.). To su:

1. altruistička motivacija - djecu se želi imati da bi im se pružala ljubav i zaštita, da bi se za njih brinulo ...

2. fatalistička motivacija - smisao života muškarca, odnosno žene, jest reprodukcija i produžavanje vrste, to je njihova sudbina i neizbježan dio života ...

3. narcistička motivacija - dijete će povećati vrijednost roditelja, ono će biti dokaz njihove maskulinosti, odnosno femininosti ...

4. instrumentalna motivacija - koja se u našim analizama pokazala multifaktorskom.

Identificirani su faktori: potvrđivanje selfa, produženje obiteljske loze, očuvanje stabilnosti braka i domoljubna motivacija. 
DRUŠ. ISTRAŽ. ZAGREB GOD. 20 (2011), BR. 4 (114),

STR. 1063-1083

LACKOVIĆ-GRGIN, K.: DOŽIVLJAJ I PRAKSA...
Za raspravu o doživljaju i praksi roditeljstva važni su neki podaci o prediktorima ovih kategorija motivacije. Tako je npr. životna dob dobar prediktor altruističke motivacije (Lacković-Grgin i Vitez, 1997.). To znači da s dobi raste spremnost pružanja ljubavi, zaštite i brige za djecu. Također se utvrdilo da je obrazovni status značajan prediktor fatalističke, narcističke i instrumentalne motivacije. Obrazovanje je značajno povezano i s roditeljskim ponašanjem. Pozitivnu povezanost između stupnja obrazovanja i kvalitete interakcije s djetetom utvrdio je Alwin (1984.). Roditelji nižeg obrazovanja skloniji su autoritarnom stilu odgoja (Lacković-Grgin, 1982; Chafel i Hadley, 2001.). Majke s višim obrazovanjem imaju više rezultate na skali prihvaćanja, pa manje od majki nižeg obrazovanja psihološki i bihevioralno kontroliraju djecu, a i očevi čije supruge imaju niže obrazovanje skloniji su psihološkoj kontroli (Keresteš, 2001.). Autoritarnost može imati negativne razvojne ishode (Maccoby i Martin, 1983.), što potvrđuju noviji rezultati, prema kojima je povećana psihološka i bihevioralna kontrola značajno povezana s internaliziranim i eksternaliziranim problemima djece (Macuka, 2007.).

Roditeljstvo nije statičan odnos s djetetom, pa ga valja promatrati kao psihološki proces koji ima svoje faze razvoja. Emocionalne i instrumentalne transakcije roditelja i djeteta događaju se u različitim životnim razdobljima sudionika tih transakcija, ali i u različitim životnim okolnostima. Poštujući razvojne značajke i potrebe djece, Kestenberg 1970. godine (prema Kapor-Stanulović, 1985.) govori o:

1. potpunom roditeljstvu (od rođenja do polaska djeteta u školu)

2. djelomičnom roditeljstvu (nakon polaska u školu, tijekom djetinjstva i adolescencije)

3. roditeljstvu bez djeteta (nakon odlaska odrasloga djeteta iz roditeljskoga doma).

Demick (2002.) navodi da doživljaj roditeljstva i roditeljsko ponašanje ovisi o kognitivnim strukturama, odnosno o tome kako roditelji koncipiraju svoju ulogu i svoju djecu. $\mathrm{Na}$ osnovi shvaćanja da je roditeljstvo važan i društveno relevantan razvojni zadatak koji se realizira na društveno sankcionirane načine, E. Galinsky je (1981.) istraživanjem utvrdila šest stadija roditeljstva. To su:

1. stadij predviđanja i zamišljanja (u razdoblju trudnoće)

2. stadij njegovanja (do druge godine djetetova života)

3. stadij autoriteta (do pete godine djetetova života)

4. stadij interpretacije (do dvanaeste godine djetetova života)

5. stadij međuzavisnosti (tijekom adolescencije)

6. stadij odlaska iz roditeljskoga doma. 
DRUŠ. ISTRAŽ. ZAGREB GOD. 20 (2011)

BR. 4 (114),

STR. 1063-1083

LACKOVIĆ-GRGIN, K. DOŽIVLJAJ I PRAKSA...
Proces roditeljstva doživljava svojevrsnu renesansu kad odrasla osoba postane baka ili djed, jer tada još jednom proživljavaju vlastito roditeljstvo iz njegove prve faze. Ta ekstenzija roditeljstva, s obzirom na iskustvo i prirodu odnosa s unucima kao i odnosa s odraslom djecom, obilježena je nekim dodatnim zadaćama, kao što su npr. zamjenska briga o djeci kad su roditelji odsutni ili su se razveli, održavanje obiteljskoga kontinuiteta i mudrosti obiteljskoga života (Matthews i Sprey, 1985.; Johnson, 1988.).

Navedene i druge podjele roditeljstva u nejednakoj mjeri impliciraju razvojne značajke roditelja i djece. Te značajke valja posebno poštovati, jer one dugotrajno određuju promjenjivu prirodu transakcija roditelja i djece.

Stoga je cilj ovoga rada razmotriti neke osobitosti roditeljstva s obzirom na razvojne značajke roditelja i djece.

\section{RODITELJSTVO U ADOLESCENCIJI}

Za mnoge parove normativna tranzicija $u$ roditeljstvo jest stresni životni događaj, posebice u žena (Terry i sur., 1996.). Još i više to je stresan događaj u adolescenciji, osobito u ranijem adolescentnom razdoblju, $\mathrm{u}$ kojem je dobiti dijete nenormativni životni događaj. $U$ većini društava prijelaz $u$ roditeljstvo obilježava nekoliko elemenata, od kojih ćemo razmotriti sljedeća dva:

1. dobiti dijete legitimno je $u$ bračnoj ili trajnijoj izvanbračnoj vezi, a ne u kratkoj, više ili manje romantičnoj vezi, odnosno roditeljstvo treba proizaći iz relativno trajne seksualne veze

2. društvena su očekivanja da roditelji budu odrasli ljudi, tj. da je proces razvoja njihova relacijskog, profesionalnog $\mathrm{i}$ seksualnog identiteta završio, kako bi od djece svojih roditelja mogli postati roditelji svoje djece.

Trajna seksualna veza posjeduje određenu posebnost $u$ odnosu na kratkotrajne i usputne veze. Radi se zapravo o tome da trajnija veza osigurava povjerenje koje roditeljskom paru pruža potencijal za uspostavljanje dobrih međusobnih odnosa, kao i odnosa prema potomstvu. Romantične i seksualne veze $u$ adolescenciji relativno su kratkotrajne (Shulman i Seiffge-Krenke, 2001.), pa je razlaz partnera u trudnoći ili nakon rođenja djeteta prilično očekivan. Rabin (1965.) navodi da oko 50 posto američkih studenata smatra kako su za muškarce najvažniji narcistički motivi za roditeljstvo. Mladićima seksualne veze služe u prvom redu za dokazivanje maskulinosti te za izgradnju seksualnog identiteta (Heaven, 1994.), pa je bijeg od roditeljske odgovornosti vjerojatniji kod adolescentnih očeva.

Prerano roditeljstvo potiče nekoliko dramatičnih procesa, koji se razlikuju s obzirom na spol adolescenata. 
DRUŠ. ISTRAŽ. ZAGREB GOD. 20 (2011), BR. $4(114)$

STR. 1063-1083

LACKOVIĆ-GRGIN, K.: DOŽIVLJAJ I PRAKSA..
U zadnjih dvadesetak godina većina majki adolescentica prihvaća brigu o svojoj djeci, s partnerom ili bez njega, uz pomoć i podršku obitelji, ili pak kao samohrane majke. Bez obzira na količinu pomoći u brizi za dijete, prerano majčinstvo ima trajne posljedice za obrazovni i radni status tih adolescentica, posebice onih koje su samohrane. Jedna nacionalna studija iz 2001. godine u SAD-u, pokazala je da čak 75 posto od sve djece samohranih adolescentica raste $\mathrm{u}$ siromaštvu (Mollborn, 2007.). Takve majke, nažalost, budući da i same pripadaju nižem socioekonomskom statusu, ni kasnije u životu ne postižu više obrazovanje, a ni bolji materijalni status.

Prihvaćanje očinstva u adolescentnoj dobi pokazuje više mogućnosti. Neki mladi očevi nikada ne prihvate tu ulogu, pa je biološko očinstvo početak i kraj njihova roditeljstva. Druga je krajnost prihvaćanje pune odgovornosti za dijete, zbog čega se prekida školovanje, što ima dugotrajne ekonomske i socijalne posljedice, posebice za one koji postaju očevi prije 18. godine (Mollborn, 2007.). Suvremena literatura o očinstvu adolescenata izvješćuje da su u većini kultura mladići ipak uključeni u tijek trudnoće i u brigu o djetetu, uz dodatnu pomoć obitelji ili zajednice (Heron i sur., 2003.). Isto kao i majke, takvi očevi jesu i ostaju slabijega obrazovnog i materijalnog statusa. Izloženi su socijalnom isključenju, što ih čini ranjivima i neprilagođenima. Loša kvaliteta očinstva u adolescentskoj dobi nerijetko proizlazi i iz činjenice da je rano očinstvo često povezano $\mathrm{s}$ delinkventnim, pa i kriminalnim, ponašanjem prije i poslije rođenja djeteta (Gottfredson i Hirschi, 1990.). O stresnosti očinstva $u$ adolescenciji govore i podaci istraživanja na jednom uzorku mladih, gdje je kod 20 posto mladih očeva porasla depresivnost pri tranziciji u roditeljstvo, a čak 37 posto njih izrazilo je potrebu za kliničkom pomoći (Vaz i sur., 1983.).

Kad adolescentni roditelji i započnu trajnu vezu (bračnu ili izvanbračnu) s nadom da će veza postati stabilna, a briga o djetetu zajednička, postoji značajna mogućnost njezina ranog raspada (Kellam i sur., 1982.). U takvim slučajevima dodatni problemi i stres slabe brigu za dijete u obliku emocionalnoga zanemarivanja male djece i u stihijskom stilu odgoja djece.

Glede društvenih očekivanja o optimalnom vremenu dobivanja djece, valja istaknuti da ona počivaju na iskustvima o poteškoćama roditeljstva kod mladih ljudi koji nisu postigli zadovoljavajuću razinu osobne zrelosti. Transverzalna i longitudinalna istraživanja započeta potkraj 1970-ih godina potvrđivala su ne samo postojanje obrazovnih $i$ financijskih problema nego i psiholoških problema adolescenata koji su postali majke i očevi (Furstenberg, 1976.; Card i Wise, 1978.; Hofferth i Moore, 1979.; Osofsky, 1982.). Ti problemi mogu proizlaziti iz sljedećih izvora: 1. psihološka nezrelost; 2 . manjak roditeljskih vještina; 3 . ekonomski stres; 4. stres zbog odustajanja od realizacije razvojnih zadataka adolescentne dobi. 
DRUŠ. ISTRAŽ. ZAGREB GOD. 20 (2011) BR. 4 (114),

STR. 1063-1083

LACKOVIĆ-GRGIN, K. DOŽIVLJAJ I PRAKSA...
Postati roditelj prije uspješnoga rješenja krize identiteta (Erikson, 1984.) riskantno je iz više razloga. Prvo, briga o djetetu ometa posvećenost razvoju identiteta, kao i proces individuacije, koji uključuje slabljenje i mijenjanje prirode veze s roditeljima (Blos, 1979.). Potreba za pomoći roditelja oko podizanja prerano prispjeloga djeteta usporava taj proces. Stoga neki adolescenti izbjegavaju emocionalnu i instrumentalnu podršku roditelja, što može biti riskantno iz više razloga. Adolescenti mogu manje od odraslih donositi racionalne odluke $u$ ulozi roditelja, a skloni su odupirati se autoritetu svojih roditelja, čije načine roditeljskoga ponašanja kritiziraju. Zbog toga se ne žele koristiti njihovim roditeljskim iskustvima, a vlastitih nemaju dovoljno. Nadalje, zbog specifičnih razvojnih zadataka i nedovoljne kognitivne zrelosti, adolescenti su usmjereni na sebe (Adams i Jones, 1981.), pa im roditeljska uloga nije salijentna. Osim što o toj ulozi premalo znaju, oni slabo poznaju i karakteristike male djece. Roditeljstvo nerijetko percipiraju kao barijeru koja im priječi omiljene aktivnosti koje prakticiraju njihovi vršnjaci (izlasci, zabave i slično). Zbog socijalnog isključivanja mladići trajno ostaju socijalno izolirani (Sigle-Rushton, 2005.). Adolescenti teže kontroliraju svoja raspoloženja, pa su prema djeci emocionalno i ponašajno ambivalentni. Zbog toga brigu o djeci neki potpuno prevaljuju na svoje roditelje, rođake ili ih smještaju u ustanovu. Kad se same brinu o djeci, adolescentice imaju poteškoća u prepoznavanju dječjih potreba, tj. nedostaje im senzitivnost, koju brojni autori smatraju centralnom komponentom efikasnoga roditeljstva (Lamb i Easterbrooks, 1981., prema Lamb i Elster, 1986.; Ainsworth i sur., 1978.; Zeanah i sur., 1997.). One više od starijih majki njeguju neverbalnu interakciju s djecom, obavljajući šutke poslove njegovanja (Levine i sur., 1985.). Nerijetko podcjenjuju dječje potrebe i sposobnosti, što nepovoljno utječe na kognitivni razvoj djece. Teško se nose s fizičkim zahtjevima $u$ fazi vegetativne ovisnosti djeteta, pa pate od kroničnog umora, gubitka sna i slično, a neke zapadaju u depresivna raspoloženja i zanemaruju djecu. Nažalost, neke postaju agresivne ili se prema djeci ponašaju nekonzistentno (Sollie i Miller, 1980.).

Sve opisano otežava razvoj rane privrženosti, koja utječe na kvalitetu međuljudskih odnosa u kasnijim razdobljima života. Takva djeca mogu postati odrasle osobe niskoga samopoštovanja, koje će teško uspostavljati bliske veze i odnose (Hazan i Shaver, 1987.; Fraley, 2002.), s rizikom da i same prakticiraju negativne oblike roditeljskoga ponašanja.

\section{RODITELJSTVO U MLAĐOJ ODRASLOJ DOBI}

Uspješno rješenje krize intimnosti nasuprot izolaciji predstavlja osnovicu za kvalitetno roditeljstvo u mlađoj odrasloj dobi, jer omogućuje psihosocijalnu stečevinu, što Erikson naziva lju- 
DRUŠ. ISTRAŽ. ZAGREB GOD. 20 (2011), BR. 4 (114), STR. 1063-1083

LACKOVIĆ-GRGIN, K. DOŽIVLJAJ I PRAKSA. ma i spremnost za odricanje i kompromis. Ljubav se izražava u brizi, poštovanju drugoga i odgovornosti prema drugome. Upravo zato, za razliku od adolescencije, mlađa odrasla dob smatra se dobrim vremenom za roditeljstvo.

U mnogim društvima napuštanje roditeljskoga doma, sklapanje braka ili trajne romantične veze te dobivanje djece predstavljaju značajne tranzicije u obiteljskome životu. Društvena su očekivanja da mlađi odrasli ostvare navedene tranzicije. U nekim kulturama i tradicionalnim sredinama dobiti dijete nije samo očekivani događaj nego i jasno izražen društveni zahtjev, ispunjenje kojega mladima osigurava atribut odraslosti i potvrdu rodne uloge. Mlađa odrasla dob smatra se dobrim vremenom za roditeljstvo ne samo zbog bioloških nego i zbog socijalnih i psiholoških razloga. Mlađi odrasli u vezi s roditeljstvom donose racionalne odluke, što je neobično važno u modernim društvima na Zapadu, gdje se stavovi prema obligaciji roditeljstva sve više liberaliziraju (Adler, 1997.), kao što se liberaliziraju i stavovi o oblicima roditeljstva. U autonomnom odlučivanju kad će postati roditelji procjenjuju se objektivne okolnosti njihova života i realizacija nekih drugih zadataka vezanih uz ovo životno razdoblje. U namjeri da roditeljstvo u socijalnom i psihološkom smislu bude što kvalitetnije, zadnjih se desetljeća pomiče vrijeme rođenja prvoga djeteta prema kasnijoj kronološkoj dobi. Statistike u nekim sjeverno-europskim zemljama govore o prosječnoj dobi od 29 godina, u mediteranskim zemljama prvo se dijete dobiva sa 24 godine (De Valk i Liefbroer, 2007.), a kod nas, prema statistici Hrvatskog zavoda za javno zdravstvo, prosječna dob prvorotkinja jest 27 godina. Varijacije ovoga trenda ovise o obrazovnoj i religijskoj pripadnosti roditelja tih mladih ljudi.

Dobro odabrano vrijeme za dobivanje djeteta kod oba roditelja može olakšati prihvaćanje roditeljske uloge, tj. usvajanja majčinskoga, odnosno očinskog, identiteta. Prema Strykerovoj teoriji identiteta (Stryker, 1987.), roditeljska predanost djetetu jest funkcija a) istaknutosti te uloge u njihovu samopoimanju, b) zadovoljstva što ga ta uloga pruža i c) percepcija da je ta uloga pozitivno vrednovana od značajnih drugih (bračnog partnera, roditelja, prijatelja). Fox i Bruce (2001.) doista nalaze da je istaknutost očinske uloge ključan prediktor očinskih stavova i ponašanja, očinske odgovornosti i uključenosti u dječje aktivnosti. U jednoj drugoj studiji utvrđeno je da pozitivna vrednovanja očinstva pridonose većoj uključenosti očeva u brigu oko djece (Eggebeen i Knoester, 2001.). Uključenost očeva povezana je s manje stresa pri tranziciji u roditeljstvo. Naime, ta tranzicija može biti uznemirujuća za oba člana bračnoga para (Cowan i Cowan, 1992.), zbog čega opada bračno zadovoljstvo. Najnovije studije govore da se uzroci tog opadanja razlikuju s obzirom na spol roditelja, a da su zajednički uzroci umor i manjak sna te povećanje kućanskih obaveza (Brotherson, 2007.). 
DRUŠ. ISTRAŽ. ZAGREB GOD. 20 (2011) BR. 4 (114),

STR. 1063-1083

LACKOVIĆ-GRGIN, K. DOŽIVLJAJ I PRAKSA...
Izgrađeni roditeljski identitet povezan s realnim očekivanjima od djece i poštivanje osobitosti njihova sveukupnog razvoja u pojedinom razvojnom stadiju, kao i adekvatna potpora okoline, omogućuju uspješnu roditeljsku praksu i povoljan utjecaj na razvoj djece u njihovim prvim godinama. Istraživački rezultati pokazuju (Cox i sur., 1989.; Helms-Erikson, 2001.; Feeney, 2003.) da u tome razdoblju na doživljaj zadovoljstva u roditeljskoj ulozi utječu: a) kvaliteta odnosa roditeljskoga para, b) sposobnost dobre organizacije obiteljskoga života, u kojem svojim doprinosom sudjeluju oba roditelja, c) životna dob roditelja.

Glede životne dobi, istraživanje Ragozina i suradnika (1982.) kod prvorotkinja u dobi od 16 do 38 godina pokazuje da mlađe majke imaju manje zadovoljavajućih osjećaja prema dojenčadi od starijih majki. Majčinski su osjećaji to viši što su prvorotkinje starije. Istraživači su majčinske osjećaje operacionalizirali kao: zadovoljstvo interakcijom s dojenčetom, pozitivni emocionalni ton $\mathrm{u}$ odnosu s dojenčetom i osjetljivost za djetetove potrebe. Čini se da utvrđeno nije samo posljedica veće osobne zrelosti tih žena nego vjerojatno i činjenice da im otkucava "biološki sat", pa njihova visoka motivacija za roditeljstvo rezultira navedenim majčinskim ponašanjem. Opažanja ponašanja pokazala su i da mlađe majke provode manje vremena sa svojom dječicom. Ovi rezultati govore u prilog suvremenim tendencijama dobivanja prvoga djeteta u kasnijoj dobi od one koja je bila uobičajena u ranijim generacijama roditelja.

Osjećaj kompetencije i zadovoljstvo roditeljstvom varirat će u vezi s razvojnim značajkama djece. Mala djeca, posebice ona tzv. teškoga temperamenta, povećavaju stres u roditeljskoj ulozi i onda kad su sve pripreme za tu ulogu bile zadovoljavajuće. Svakodnevna interakcija s takvim djetetom emocionalno uznemiruje roditelje, pa može provocirati odbacivanje ili agresivno ponašanje. To se posebice odnosi na one koji imaju prevelika očekivanja uspjeha u napredovanju svoje djece, koji ne mogu uspješno rješavati probleme međusobnog odnosa ili pojedinačne probleme povezane $s$ funkcioniranjem $u$ nekim drugim ulogama (uloga supruge, profesionalna uloga ili neka druga obiteljska uloga). Brajša-Žganec (2002.) utvrđuje da ako su roditelji svjesni vlastitih i dječjih negativnih emocija i ako se oni s njima dobro nose, njihova će djeca imati manje internaliziranih i eksternaliziranih problema.

Doživljaj roditeljstva kad su djeca u kasnom djetinjstvu, osim što ovisi o prirodi djeteta, ovisi i o promjenama njegova društvenoga statusa. Dijete postaje učenik, pa prema njemu rastu zahtjevi u vezi sa školovanjem, koje za dijete ne mora biti uspješno, posebice ako su roditeljska očekivanja prevelika. Procjene djeteta kako ih vidi nastavnik i uspjeh u školi mogu povećati ili smanjiti roditeljsko zadovoljstvo. Ako dijete ima intelektualne ili emocionalne probleme u razvoju, zbog kojih 
DRUŠ. ISTRAŽ. ZAGREB GOD. 20 (2011), BR. $4(114)$

STR. 1063-1083

LACKOVIĆ-GRGIN, K.: DOŽIVLJAJ I PRAKSA. postiže slabiji uspjeh u školi, ili se problematično ponaša, roditelji mogu doživjeti osjećaj bespomoćnosti i nezadovoljstva. Poteškoće u upravljanju djecom u kasnom djetinjstvu, ali i u adolescenciji, snizuju samopoštovanje majki, koje su i u suvremenim obiteljima ipak odgovornije za odgoj djece. Kako je otac obično više zadužen za osiguravanje materijalne dobrobiti djece, ako u tome uspijeva, može doživjeti porast samopoštovanja (Maccoby, 1980.).

Kod roditelja s djecom u fazi puberteta zadovoljstvo može opasti ako oni teško podnose porast mladenačke nezavisnosti i dječje relativiziranje roditeljskog autoriteta. Roditelji koji su i ranije prakticirali kontrolu počinju pojačavati bihevioralnu i psihološku kontrolu, koja je izraženija prema dječacima (Keresteš, 2001.). Iskazivanje nježnosti opada, posebice u majki, pa mladi postaju emocionalno ambivalentni. Kod adolescenata delinkventnoga ponašanja, majke i očevi počinju prakticirati odbacivanje ili se ponašaju neprijateljski (Peterson i Hann, 1999.). S druge strane, roditelji demokratskoga stila upravljanja razvoj dječjih intelektualnih i socijalnih kompetencija i njihovu sve veću nezavisnost doživljavaju kao ostvarenje svojih roditeljskih vrijednosti i ciljeva, pa su i zadovoljniji roditeljstvom.

O praksi roditeljstva povezanoj s istaknutosti uloga potkraj mlađe odrasle dobi govore rezultati što su ih dobili Baruch i suradnici (1983.). Sve ispitane majke bile su službenice $\mathrm{i}$ imale su djecu adolescentne dobi. Ispitivanjem su identificirana dva tipa majčinstva, i to: autonomno i spojeno majčinstvo. Autonomno majčinstvo prati doživljaj ponosa što njihova djeca postaju samostalne, zrele i omiljene osobe. Te majke imaju visoko samopoštovanje i osjećaj da kontroliraju svoj život. Spojeno majčinstvo doživljava se kao osjećaj da samo djeca daju smisao životu i da su one nezamjenjive u dječjim životima. U usporedbi s autonomnim majkama, imaju niže samopoštovanje, više se žale na svoj život te su anksiozne ili depresivne. Drugim riječima, zadovoljstvo roditeljstvom veće je kad promjene $u$ dječjem razvoju prate adekvatne promjene roditeljskog odnosa prema djeci. Nužne promjene, pa i prekretnice, $\mathrm{u}$ roditeljskom ponašanju prema adolescentima ili pak konzistentnost ponašanja kakvo se ranije prakticiralo odrazit će se na doživljaj i praksu roditeljstva i u srednjoj odrasloj dobi, kad im djeca postupno prelaze u mlađu odraslu dob.

\section{RODITELJSTVO U SREDNJOJ ODRASLOJ DOBI}

Tijekom srednje odrasle dobi, pošto je u ranijim stadijima razvoja uspješno stečen osjećaj identiteta i intimnosti, glavno pitanje koje si ljudi postavljaju jest: jesu li stvorili nešto do čega im je osobito stalo? Motivirani su očuvati, ali i unaprijediti, ono što su stvorili, jer još procjenjuju da to mogu. Po Eriksonovu mišljenju, u tom stadiju života razvija se generativ- 
DRUŠ. ISTRAŽ. ZAGREB GOD. 20 (2011)

BR. 4 (114),

STR. 1063-1083

LACKOVIĆ-GRGIN, K. DOŽIVLJAJ I PRAKSA... nost koju on definira kao ..."brigu za stvaranje i vođenje sljedeće generacije" (Erikson, 1984., 240). U prvom redu to je briga za vlastito potomstvo, ali jednako tako to je i briga za mlađu generaciju općenito, kako bi se preko nje očuvale postojeće materijalne i kulturne vrijednosti. Iako se Vaillant (1997.) razlikuje od Eriksona u opisu nekih stadija razvoja, i on smatra da se o generativnosti može govoriti kao o: 1 . brizi za konkretne osobe $u$ obitelji ili na radnome mjestu i 2 . kao nalaženju smisla života u brizi za buduće generacije općenito. Takvu vrstu djelovanja od odraslih ljudi očekuje i šira društvena zajednica. Neki istraživači tvrde da osobe s prethodnim iskustvom roditeljstva, koje su generativne u brizi za vlastitu djecu, mogu uspješnije realizirati brigu za buduće generacije općenito (Snarey i Clark, 1998.). Naše komparativno istraživanje generativnoga djelovanja $\mathrm{u}$ dvije tranzicijske zemlje pokazuje da visoka procjena važnosti roditeljstva u odraslih ljudi predstavlja značajan prediktor generativnoga djelovanja u Sloveniji, ali ne i u Hrvatskoj (Penezić i sur., 2008.). Valja istaknuti da mnogi odrasli ljudi koji su prikraćeni osobnoga roditeljskog iskustva mogu iskazivati visok stupanj generativnoga djelovanja u zajednici, zbog svojih životnih ciljeva, odnosno životne orijentacije prema djelovanju i zajedništvu.

Generativnost $\mathrm{u}$ obliku tendencije djelovanja i tendencije zajedništva iskazuje se i u roditeljskoj ulozi. Generativno djelovanje odnosi se na kreaciju djela koje je "spomenik" sebi samome, što u prvom redu vrijedi za osobe narcističke i instrumentalne motivacije za roditeljstvo. U roditelja srednje odrasle dobi generativno se djelovanje ogleda u pomaganju da im sinovi i kćeri postignu što povoljniji materijalni i profesionalni status. Očevi sinovima nastoje priskrbiti trajnija materijalna dobra. Majke pak pomažu kćerima da postižu obrazovne i profesionalne ciljeve, posebice ako same nisu u tome uspjele ili ako općenito nisu zadovoljne svojom tradicionalnom rodnom ulogom. One spremno preuzimaju dijelove odgovornosti koje proizlaze iz salijentnih uloga u životu njihovih odraslih kćeri. Međutim, kad njihova odrasla djeca ne djeluju u skladu s opisanim roditeljskim nastojanjima, javit će se ambivalencija u njihovu odnosu, koja može umanjiti zadovoljstvo roditeljstvom. Literatura posvećena proučavanju tih odnosa uglavnom je bila usredotočena na pozitivne i negativne aspekte odnosa roditelja srednje i starije odrasle dobi i njihove odrasle djece (za pregled pogledati: Lüscher i Pillemer, 1998.). Majke su više od očeva ambivalentne prema djeci ako ona nisu postigla ili nisu održala normativni status odrasle osobe, posebice ako nisu postala financijski neovisna (Pillemer i Suitor, 2002.). Pojavljuju se i razlike s obzirom na dob majki i kćeri. Mlađe majke, čija je dob bliža dobi njihovih odraslih kćeri, puno su zadovoljnije odnosima s njima nego one koje su od kćeri osjetno starije. Vje- 
DRUŠ. ISTRAŽ. ZAGREB GOD. 20 (2011), BR. 4 (114),

STR. 1063-1083

LACKOVIĆ-GRGIN, K.: DOŽIVLJAJ I PRAKSA. rojatno generacijske razlike $\mathrm{u}$ stavovima i vrijednostima dovode do konflikata. Neosporno je utvrđeno da najviše ambivalencije u odnosima s djecom ima u onih roditelja koji nisu u stanju uspješno riješiti konflikt između želje da pomažu djeci i želje da im djeca budu nezavisna. Takvi konflikti slabe bliskost u međusobnim odnosima. Možda su konflikti vjerojatniji u tradicionalnim sredinama, jer sredovječni teško podnose promjene normativnih očekivanja. Tu pretpostavku valjalo bi provjeriti.

Jedan od izvora ambivalentnog odnosa s djecom kod sredovječnih ljudi povezan je sa slabljenjem zdravlja ili s nekim razvojnim fenomenima, kakva je npr. menopauza. Kad roditeljima slabi zdravlje, ili su poput majki u menopauzi usmjereni na svoje stvarne ili fiktivne probleme, generativno se djelovanje ne iskazuje na očekivan način.

Generativnost djelovanja može biti osujećena zbog odlaska odrasle djece od kuće, što rezultira smanjenjem zadovoljstva životom i roditeljstvom. Fenomen je poznat pod nazivom "efekt praznoga gnijezda" (Neugarten, 1970.; Gee i Kimball, 1987.). Iako se ranije smatralo da su posljedice praznoga gnijezda univerzalne, posebice u majki, pokazuje se da samo neke žene doživljavaju pad životnoga zadovoljstva u toj fazi zvanoj roditeljstvo bez djece. To su nisko obrazovane i nezaposlene majke (Neugarten, 1970.). Nezaposlenost je povezana s većom salijentnosti majčinske uloge, a niže obrazovanje i sa stereotipnim shvaćanjem te uloge. U našem smo istraživanju kod gradskih žena i žena iz manjih mjesta otoka Korčule utvrdili da je nakon odlaska odrasle djece niže životno zadovoljstvo povezano sa stereotipnim shvaćanjem majčinske uloge (Lacković-Grgin, 1993.). Budući da stereotipije nisu bile povezane s procjenom ranijega životnog zadovoljstva, čini se da kad majke stereotipna shvaćanja svoje uloge izgube svakodnevnu brigu o djeci, njihovo zadovoljstvo opada. U mnogih zaposlenih i obrazovanih žena ta životna tranzicija zapravo povećava zadovoljstvo (Neugarten, 1970.), jer se mogu više posvetiti aktivnostima koje su bile zanemarene zbog brige o djeci. Zadovoljstvo roditeljstvom očeva čija djeca napuštaju roditeljski dom više je povezano s ponosom što su djeca "stala na svoje noge", ali i s oslobađanjem ženinih kapaciteta za brigu koju one tada mogu posvećivati njima ili zajedničkim aktivnostima u slobodno vrijeme.

Generativnost zajedništva usmjerena je na njegovanje generativnog objekta, pri čemu život tog objekta postaje važniji od vlastita zato da bi se osigurala budućnost djece, ali i čovječanstva. Generativni objekti mogu biti vlastita djeca, materijalna i kulturna dobra što ih je stvorilo čovječanstvo, ali i čuvanje planeta Zemlje. Mnogim roditeljima u odrasloj dobi doživljaj roditeljstva pomućen je kad u društvu dolazi do kriza globalnih razmjera, jer krize prijete budućnosti njihove 
DRUŠ. ISTRAŽ. ZAGREB GOD. 20 (2011) djece. O tome najbolje svjedoče današnje generacije sredovječnih roditelja, koji zbog nezaposlenosti više ne mogu biti siguran oslonac svojoj djeci. Oni se srame što u razdoblju u kojem su planirali generativno djelovati $\mathrm{u}$ korist svoje djece nerijetko postaju oni koji trebaju njihovu pomoć. Dakle, društveni poremećaji, a ne samo načini obnašanja roditeljske uloge, izvor su ambivalentnih osjećaja i ambivalentnih socijalnih odnosa odraslih ljudi i njihove adolescentne ili odrasle djece.

\section{RODITELJSTVO U STARIJOJ ŽIVOTNOJ DOBI}

U starijoj životnoj dobi osobe se susreću sa slabljenjem svojih tjelesnih i psihičkih funkcija, kao i s drugim gubicima, poput slabljenja materijalnoga položaja i opadanja širine socijalne mreže zbog smrti bliskih osoba, zbog smještaja u domove za stare ili zbog nepokretnosti. Sve te promjene ugrožavaju integritet starijih ljudi, pa oni pokušavaju rješavati krizu integriteta prema očaju, o kojoj govori ne samo Erikson nego i drugi autori. Stariji ljudi nastoje dati smisao svojem životu i očuvati životno zadovoljstvo dvjema strategijama. Prva je strategija bihevioralna, a svodi se na pokušaje da se održi funkcioniranje makar i na nižim razinama. To omogućuje brigu o samome sebi, kao i zadržavanje nekih aktivnosti u salijentnim ulogama, kakva je npr. roditeljska. Ova strategija uspješnija je u ranoj staroj dobi. Druga je strategija kognitiona, u obliku retrospekcije života, prisutnija u kasnoj staroj dobi. Retrospekcijom stara osoba može analizom izlučiti sve ono u čemu je uspjela i time postići integritet. Ako pak retrospekcijom markira samo loše događaje i procijeni da je život bio pun neuspjeha i promašaja, javit će se očaj. Kod osoba koje svoje roditeljstvo ocijene neuspješnim javit će se životno žaljenje, jer znaju da više nemaju snage ni prilike išta promijeniti. One pritom mogu emocionalno odbacivati svoju djecu, izbjegavati susrete s njima, lišiti ih nasljedstva i sl.

U literaturi o odnosima starih roditelja i njihove odrasle djece dominiraju radovi u kojima je, na neki način, promijenjena perspektiva gledanja na doživljaj i praksu roditeljstva. Interes istraživača pomaknut je na brigu što ih odrasla djeca vode o ostarjelim roditeljima ili na to kako ostarjeli roditelji funkcioniraju u ulogama baka i djedova. Neke od tih studija ipak omogućuju uvid u doživljaj i praksu roditeljstva iz perspektive starih ljudi. Radi se o podacima prikupljenima $u$ istraživanjima prilagodbe starih ljudi na razne životne događaje.

Veze starih ljudi i njihove odrasle djece u današnjem su zapadnom svijetu znatno emocionalnije i bliže nego u proteklim vremenima. U mnogim društvima to je veza na distanci, jer te generacije žive svoje nezavisne živote. Kontakti su relativno česti i bliski u prilikama koje pobuđuju potrebu za iska- 
DRUŠ. ISTRAŽ. ZAGREB GOD. 20 (2011), BR. $4(114)$

STR. 1063-1083

LACKOVIĆ-GRGIN, K.: DOŽIVLJAJ I PRAKSA.. svojom roditeljskom pozicijom. Ispitivanja doživljaja bliskosti pokazala su da ostarjeli roditelji tu bliskost procjenjuju višom od njihove djece (Bengston i sur., 1985.). Roditelji bliskost sa svojom djecom doživljavaju kao dokaz svojih ostvarenih ideala dobroga roditeljstva, pa umanjuju neke razlike u tome odnosu. Njihova djeca pak sebe žele vidjeti autonomnima od roditelja, pa povećavaju postojeće razlike.

U nekim tradicionalnijim kulturama Zapada (npr. u Grčkoj), ako ne žive zajedno sa svojom djecom, stari se ljudi osjećaju zanemareni i osamljeni (Jylhä i Jokela, 1990.). U takvim zemljama preteže instrumentalna motivacija za roditeljstvo, koja uključuje očekivanja da će u starosti njihova djeca živjeti s njima i brinuti o njima. Budući da su ekonomske promjene izazvale raspad društvenih odnosa tih tradicionalnih zajednica, stari su ljudi nezadovoljni svojom roditeljskom pozicijom, jer se ne ostvaruju njihovi ciljevi vezani uz roditeljstvo, ali ni uz druge vrijednosti koje su ranije usvojili. Oni pak koji žive s djecom nisu zadovoljni roditeljstvom ako su im djeca okupirana svojim obvezama.

I u modernim kulturama postoje slučajevi da stariji ljudi žive s djecom zato što su, iz nekih razloga, ta odrasla djeca nesposobna da se brinu o sebi. Takva djeca ili nisu nikad napustila roditeljski dom, jer se nisu ekonomski i emocionalno osamostalila, ili su se zbog osobnoga sloma vratila roditeljima. Uzroci toga sloma različiti su, a najčešće se navode slučajevi razvoda braka u srednjoj odrasloj dobi, dugotrajna ovisnost o drogama, alkoholizam, gubitak zaposlenja i druge tragične okolnosti (Mancini i Blieszner, 1989.). U takvim slučajevima stariji roditelji ne samo da materijalno osiromašuju jer im djeca nisu financijski neovisna nego neki od njih ponekad trpe i nasilna ponašanja svoje djece. Rezultati pokazuju da su očevi češće žrtve takva nasilja od majki (Martin, 1989., prema Perlmutter i Hall, 1992.).

U ekonomski razvijenim društvima Zapada stari roditelji i djeca žive zajedno kad su stari siromašni, bolesni ili su izgubili bračnoga partnera. Budući da su žene obično mlađe od svojih muževa, a i žive u prosjeku nekoliko godina duže od muškaraca, $\mathrm{k}$ svojoj djeci majke dolaze živjeti češće nego očevi. Prema nekim istraživanjima na nacionalnim uzorcima, to se događa u 80 posto slučajeva, pri čemu se u oko 66 posto slučajeva dolazi živjeti u dom svojih kćeri (Hagestad, 1986., 1988.). Bake preuzmu dio briga za unučad, što značajno utječe na njihovo roditeljsko, ali i životno, zadovoljstvo. Antropologijska istraživanja pokazuju da i u primitivnim i u suvremenim zajednicama nježan i brižan odnos prema djeci dok su malena predstavlja zalog dobre pozicije ostarjelih, čak i u teškom siromaštvu. Suprotno tome, grubost prema djeci povezana je s odsutnosti suosjećanja sa starim roditeljem, pa prilikom umi- 
DRUŠ. ISTRAŽ. ZAGREB GOD. 20 (2011), BR. 4 (114),

STR. 1063-1083

LACKOVIĆ-GRGIN, K. DOŽIVLJAJ I PRAKSA... ranja majke iz sibirskoga plemena Jakuta najstariji sin bez milosti govori da je i on patio zbog njezinih postupaka kad je bio malen (S. de Beauvoir, 1987.).

Preuzimanje dijela brige za unučad percipirano je kao važan faktor koji pridonosi dobrobiti starijih ljudi, posebice žena. Poznata longitudinalna Bonska studija starenja (BOLSA, Lehr i Thomae, 1987.), provedena kod osoba iz srednje klase, pokazala je da aktivnosti u ulozi roditelja ili baka i djedova nakon umirovljenja povećavaju životno zadovoljstvo kod gotovo 75 posto uzorka. Ispitanici su na početku studije imali od 60 do 75 godina. Duže su živjeli oni koji su bili integrirani u obitelj, odnosno koji su sa svojim potomcima bili emocionalno bliski. To znači da zadovoljstvo roditeljstvom ne samo da povećava zadovoljstvo životom nego i utječe na njegovu dužinu. Zanimljivo je da se obrazovanje pokazalo važnim moderatorom ove povezanosti. Kod starih visoke inteligencije i visokog obrazovanja opisana se veza nije pokazala značajnom.

Kognitivne strategije kojima stari ljudi pokušavaju učvrstiti svoj integritet istraživao je Erik Erikson sa suradnicima (Erikson i sur., 1986.). Ispitanike je pratio od mladosti do duboke starosti. Podaci zadnjih intervjua sa starima dopunjavani su arhivskim podacima iz ranijih godina praćenja, kako bi se usporedila stvarna događanja i njihova interpretacija u starosti.

Utvrđeno je da visokointegrirani stari ljudi svoj protekli život, pa i roditeljstvo, procjenjuju zadovoljavajućim. Da su dobro funkcionirali u ulozi roditelja, oni to izražavaju u tvrdnjama poput "Sva moja djeca su školovana", "Svi moji sinovi su bogati ljudi" i sl. Očaj iskazuju jedino oni stari čiju djecu prate slične nedaće kakve su i sami prolazili u njihovim godinama (nezaposlenost, rastava braka, bolest i dr.). Da bi uzvisili svoje roditeljstvo, stari pretjeruju u hvaljenju uspjeha i pameti svoje djece i svoje unučadi. Čine to i oni u čijim se dosjeima iz ranijih praćenja nalaze registrirani teški problemi u odgoju njihove djece. Osim što su u starosti skloni reinterpretirati ranije roditeljsko iskustvo, oni u tom iskustvu nerijetko traže objašnjenje za aktualan odnos s njihovom odraslom djecom. To se našlo u onih koji priznaju da im djeca ni prije ni sada nisu ljudi društveno prihvatljiva ponašanja. Generacija Eriksonovih ispitanika bili su mladi roditelji tijekom ekonomske krize i Drugoga svjetskog rata, pa on smatra da stari precjenjuju svoju djecu jer su ona objektivno ostvarila više od onoga što su oni u svojim životima mogli ostvariti. Valjalo bi istražiti postoji li tendencija idealiziranja roditeljstva i u okolnostima koje su za kohorte roditelja i djece bile relativno stabilne.

Spolne razlike $u$ interpretacijama prošloga i sadašnjega roditeljstva našle su se u iskazima žena da su se one zbog prokreacije i roditeljstva odricale svojih kreativnih aktivnosti. Kod osoba obaju spolova doživljaj roditeljstva kao žrtvovanja također se može pripisati povijesnom vremenu u kojem su ži- 
DRUŠ. ISTRAŽ. ZAGREB GOD. 20 (2011), BR. 4 (114),

STR. 1063-1083

LACKOVIĆ-GRGIN, K.: DOŽIVLJAJ I PRAKSA.

vjeli stari iz Eriksonove studije. No bez obzira na povijesno vrijeme, doživljaj roditeljstva kao žrtvovanja prisutan je u onim individualnim slučajevima u kojima su ostarjeli roditelji iz raznih razloga zanemarivani od svoje odrasle djece. Čini se da zanemarivanje posebice potencira interpretaciju majčinstva kao žrtvovanja.

Erikson, ali i neki drugi istraživači, navodi da je mnogima starima teško govoriti o svojem aktualnom doživljaju roditeljstva i o aktualnom odnosu s djecom. Procjenjujući aktualno roditeljstvo, stari se češće ponašaju pragmatično nego filozofski. Na primjer, oni govore da se brinu o djeci i daju im savjete, iako su svjesni da bi bilo bolje da šute; pomažu im financijski, premda misle da bi bilo bolje da to ne čine. Govoreći o svojem zadovoljstvu roditeljstvom, opisuju ga u terminima usluga koje im djeca čine (odvođenje u kupovinu, $\mathrm{k}$ liječniku i sl.). Za neke je to dokaz ljubavi i sklada u odnosima, kod drugih je to izvor sukoba zbog ograničavanja željene autonomije. Brigu o unučadi shvaćaju kao praksu koja može pridonijeti njihovu zadovoljstvu roditeljstvom, jer im se pruža šansa za njegovo proširenje, čime osiguravaju kontinuitet obiteljskih veza, ali i osjećaj sigurnosti članova šire obitelji.

Na kraju valja istaknuti da u suvremenoj literaturi o roditeljstvu dominiraju teorijski modeli i istraživački podaci o roditeljstvu u ranim fazama, kad su djeca u roditeljskom domu. Roditeljstvo u razdoblju srednje i starije životne dobi osjetno se manje istražuje, pa to može biti izazov za buduće istraživače. Izgledi takvih istraživanja danas su mnogo veći s obzirom na brojna metodološka poboljšanja. Tu se u prvom redu misli na veće mogućnosti organiziranja longitudinalnih studija $u$ kojima bi se dinamička priroda roditeljstva dovodila u vezu s razvojnim promjenama roditelja i djece, ali i s promjenama konteksta u kojem se odvijaju interakcije djece i roditelja. Budućim istraživačima ide u prilog i povećana otvorenost obitelji prema raznim društvenim institucijama, uključujući i znanstvene institucije.

\section{LITERATURA}

Adams, G. R. i Jones, R. M. (1981.), Imaginary Audience Behavior: A Validation Study. The Journal of Early Adolescence, 1 (1): 1-10. doi:10.1177/ 027243168100100102

Adler, M. A. (1997.), Social Change and Declines in Marriage Fertility. Journal of Marriage and Family, 59 (1): 37-49. doi:10.2307/353660

Ainsworth, M. D. S., Blehar, M., Waters, E. i Wall, S. (1978.), Patterns of Attachment, Hillsdale, NJ, Lawrence Erlbaum Associates.

Alwin, D. F. (1984.), Trends in Parental Socialization Values: Detroit 1958-1983. American Journal of Sociology, 90 (2): 359-381. doi:10.1086/ 228083

Baruch, G., Barnett, R. i Rivers, S. (1983.), Life Prints: New Patterns of Love and Work for Today Women, New York, McGraw-Hill. 
DRUŠ. ISTRAŽ. ZAGREB GOD. 20 (2011) BR. 4 (114),

STR. 1063-1083

LACKOVIĆ-GRGIN, K. DOŽIVLJAJ I PRAKSA...
Bengston, V. L., Cutler, N. E., Mangen, D. J. i Marshall, V. W. (1985.), Generations, Cohorts and Relations between Age Groups. U: R. H. Benstok i E. Shanas (ur.), Handbook of Aging and the Social Sciences, New York, Van Nostrand Reinhold.

Blos, P. (1979.), The Adolescent Passage: Developmental Issues, New York, International Universities Press.

Brajša-Žganec, A. (2002.), Roditeljske metaemocije i socijalno - emocionalni razvoj djece, Zagreb, Doktorska disertacija.

Brotherson, S. E. (2007.), From Partners to Parents: Couples and Transition to Parenthood. International Journal of Childbirth Education, 22 (2): 7-12.

Card, J. J. i Wise, L. L. (1978.), Teenage Mothers and Teenage Fathers: The Impact of Early Childbearing on the Parent's Personal and Professional Lives. Family Planning Perspective, 10 (4): 199-205. doi:10. $2307 / 2134267$

Chafel, J. A. i Hadley, K. G. (2001.), Poverty and the Well-Being of Children and Families. U: C. E, Walker i M. C. Roberts (ur.), Handbook of Clinical Child Psychology (str. 3-19), New York, Wiley.

Cowan, C. P. i Cowan, P. A. (1992.), When Partners Become Parents: A Big Life Change for Couples, New York, Basic Books.

Cox, M. J., Owen, M. T., Lewis, J. M. i Henderson, V. K. (1989.), Marriage, Adult Adjustment and Early Parenting. Child Development, 60 (5): 1015-1024. doi:10.2307/1130775

De Beauvoir, S. (1987.), Starost, Beograd, BIGZ.

Demick, J. (2002.), Stages of Parental Development. U: M. H. Bornstein (ur.), Handbook of Parenting, Vol. 3: Being and Becoming a Parent (str. 389-415), Mahwah, New Jersey, Lawrence Erlbaum Associates.

De Valk, H. A. G. i Liefbroer, A. C. (2007.), Timing Preferences for Women's Family-Life Transitions: Intergenerational Transmission among Migrants and Dutch. Journal of Marriage and Family, 69 (1): 190-206. doi:10.1111/j.1741-3737.2006.00353.x

Eggebeen, D. J. i Knoester, C. (2001.), Does Fatherhood Matter for Men? Journal of Marriage and Family, 63 (2): 381-393. doi:10.1111/j.17413737.2001.00381.x

Erikson, E. (1984.), Childhood and Society, London, Triad Paladin.

Erikson, E. H., Erikson, J. M. i Kivnick, H. Q. (1986.), Vital Involvement in Old Age, New York, Norton.

Feeney, J. A. (2003.), Adult Attachment, Involvement in Infant Care, and Adjustment to New Parenthood. Journal of Systemic Therapies, 22 (2): 16-30. doi:10.1521/jsyt.22.2.16.23344

Fox, G. L. i Bruce, C. (2001.), Conditional Fatherhood: Identity Theory and Parental Investment Theory as Alternative Sources of Explanation of Fathering. Journal of Marriage and Family, 63 (2): 394-403. doi:10.1111/j.1741-3737.2001.00394.x

Fraley, R. C. (2002.), Attachment Stability from Infancy to Adulthood: Meta-Analysis and Dynamic Modeling of Developmental Mechanisms. Personality and Social Psychology Review, 6 (2): 123-151. doi:10.1207/S15 327957PSPR0602 03 
DRUŠ. ISTRAŽ. ZAGREB GOD. 20 (2011), BR. 4 (114)

STR. 1063-1083

LACKOVIĆ-GRGIN, K. DOŽIVLJAJ I PRAKSA...
Furstenberg, F. F. (1976.), The Social Consequences of Teenage Parenthood. Family Planning Perspective, 8 (4): 148-164. doi:10.2307/2134201

Galinsky, E. (1981.), Between Generations: The Six Stages of Parenthood, New York, Berkeley.

Gee, E. M. i Kimball, M. M. (1987.), Women and Aging, Toronto and Vancouver, Butterworths.

Gottfredson, M. i Hirschi, T. (1990.), A General Theory of Crime, Stanford, CA, Stanford University Press.

Grzywacz, J. G. i Marks, N. (2000.), Reconceptualizing the Work-Family Interface: An Ecological Perspective on Correlates of Positive and Negative Spillover between Work and Family. Journal of Occupational Health Psychology, 5 (1): 111-126. doi:10.1037//1076-8998.5.1.111

Hagestad, G. O. (1986.), The Aging Society and Family Life. Daedalus, 115 (1): 119-139.

Hagestad, G. O. (1988.), Demographic Changes and the Family Life Course: Some Emerging Trends in the Family Realm. Family Relations, 37 (4): 405-410. doi:10.2307/584111

Hazan, C. i Shaver, P. R. (1987.), Romantic Love Conceptualized as a Attachment Process. Journal of Personality and Social Psychology, 52 (3): 511-524. doi:10.1037//0022-3514.52.3.511

Heaven, P. C. L. (1994.), Contemporary Adolescence: A Social and Psychosocial Approach, Melbourne, McMillan Education Australia, Pty. Ltd.

Helms-Erikson, H. (2001.), Marital Quality Ten Years after the Transition to Parenthood: Implications of the Timing of Parenthood and the Division of Housework. Journal of Marriage and the Family, 63 (4): 1099-1110. doi:10.1111/j.1741-3737.2001.01099.x

Heron, E. A., McLoughlin, S. C. i Granato, R. A. (2003.), Preventing Adolescent Fatherhood, http://www.sph.uth.tmc.edu:8053/chp/ph/1110/ sateenpregl.html (pristup ostvaren 10. 10. 2003.).

Hofferth, S. L. i Moore, K. A. (1979.), Early Childbearing and Later Economic Well-Being. American Sociological Review, 44 (5): 784-815. doi:10.2307/2094528

Hoffman, L. W. (1987.), The Value of Children to Parents and Child-Rearing Patterns'. U: C. Kagitcibasi (ur.), Growth and Progress in Cross-Cultural Psychology (str. 159-170), Berwyn, Swets North America Inc.

Johnson, C. L. (1988.), Active and Latent Functions of Grandparenting during the Divorce Process. The Gerontologist, 28 (2): 185-191. doi:10. 1093/geront/28.2.185

Jylhä, M. i Jokela, J. (1990.), Individual Experiences as Cultural - a Cross-Cultural Study on Loneliness Among Elderly. Ageing and Society, 10 (3): 295-315. doi:10.1017/S0144686X00008308

Kapor-Stanulović, N. (1985.), Psihologija roditeljstva, Beograd, Nolit. Kellam, S. G., Adams, R. G., Brown, C. H. i Ensminger, M. E. (1982.), The Long-Term Evolution of the Family Structure of Teenage and Older Mothers. Journal of Marriage and Family, 44 (3): 539-544. doi:10. $2307 / 351578$ 
DRUŠ. ISTRAŽ. ZAGREB GOD. 20 (2011) BR. 4 (114),

STR. 1063-1083

LACKOVIĆ-GRGIN, K. DOŽIVLJAJ I PRAKSA...
Keresteš, G. (2001.), Spol roditelja te dob i spol djeteta kao odrednice roditeljskog ponašanja. Suvremena psihologija, 4 (1-2): 7-25.

Kochanska, G. (2001.), Emotional Development in Children with Different Attachment Histories: The First Three Years. Child Development, 72 (2): 474-490. doi:10.1111/1467-8624.00291

Lacković-Grgin, K. (1982.), Roditeljski stil rukovođenja i socijalno ponašanje učenika, Ljubljana, Doktorska disertacija.

Lacković-Grgin, K. (1993.), Psihosocijalne odrednice zadovoljstva životom u žena srednje životne dobi. Radovi, Razdio FPSP, 31 (8): 95-101.

Lacković-Grgin, K. i Vitez, S. (1997.), Predikcija Rabinovih kategorija motivacije za roditeljstvo. Radovi, FPSP, 36 (13): 43-62.

Lamb, M. E. i Elster, A. B. (1986.), Parental Behavior of Adolescent Mothers and Fathers. U: A. B. Elster i M. E. Lamb (ur.), Adolescent Fatherhood (str. 89-106), Hillsdale NJ, Lawrence Erlbaum Associates.

Lehr, U. i Thomae, H. (1987.), Formen seelischen Alterns (Ergebnisse der Bonner Gerontologischen Langschnittstudie - BOLSA), Stuttgart, Enke Verlag.

Levine, L., Garcia Coll, C. T. i Oh, W. (1985.), Determinants of Mother - Infant Interaction in Adolescent Mothers. Pediatrics, 75 (1): 23-29.

Lüscher, K. i Pillemer, K. (1998.), Intergenerational Ambivalence: A New Approach to the Study of Parent-Child Relations in Later Life. Journal of Marriage and Family, 60: (2) 413-425.

Maccoby, E. E. (1980.), Commentary and Reply. U: G. R. Patterson, Mothers: The Unacknowledged Victims. Monographs of the Society for Research in Child Development, 45 (5): 56-63.

Maccoby, E. E. i Martin, J. A. (1983.), Socialization in the Context of Family: Parent-Child Interaction. U: P. H. Mussen (ur.), Handbook of Child Psychology, Vol. 4, Socialization, Personality and Social Development (str. 1-101), New York, Wiley.

Macuka, I. (2007.), Uloga determinanti roditeljskog ponašanja u objašnjenju internaliziranih $i$ eksternaliziranih problema u djece, Magistarski rad, Zagreb, Filozofski fakultet.

Mancini, J. A. i Blieszner, R. (1989.), Aging Parents and Adult Children: Research Themes in Intergenerational Relations. Journal of Marriage and Family, 51 (2): 275-290. doi:10.2307/352492

Matthews, S. H. i Sprey, J. (1985.), Adolescents' Relationships with Grandparents: An Empirical Contribution to Conceptual Clarification. Journal of Gerontology, 40 (5): 621-626.

Mollborn, S. (2007.), Making the Best of a Bad Situation: Material Resources and Teenage Parenthood. Journal of Marriage and Family, 69 (1): 92-104. doi:10.1111/j.1741-3737.2006.00347.x

Neugarten, B. (1970.), Dynamics of Transition of Middle Age to Old Age: Adaptation and the Life Cycle. Journal of Geriatric Psychiatry, 4 (1): 71-87.

Osofsky, H. (1982.), Expectant and New Fatherhood as a Developmental Crisis. Bulletin of the Menninger Clinic, 46 (3): 209-230.

Penezić, Z., Lacković-Grgin, K., Tucak, I., Nekić, M., Žorga, S., Poljšak Škraban, O. i Vehovar, U. (2008.), Predictors of Generative Action a- 
DRUŠ. ISTRAŽ. ZAGREB GOD. 20 (2011), BR. 4 (114) STR. 1063-1083

LACKOVIĆ-GRGIN, K.: DOŽIVLJAJ I PRAKŚA... mong Adults in Two Transitional Countries. Social Indicator Research, 87 (2): 237-248.

Perlmutter, M. i Hall, E. (1992.), Adult Development and Aging, New York, John Wiley and Sons, Inc.

Peterson, G. W. i Hann, D. (1999.), Socializing Parents and Children in Families. U: S. Steinmetz, M. Susman i G. Peterson (ur.), Handbook of Marriage and the Family (str. 327-370), New York, Plenum Publishing Co.

Pillemer, K. i Suitor, J. J. (2002.), Explaining Mothers Ambivalence toward Their Adult Children. Journal of Marriage and Family, 64 (3): 602-613. doi:10.1111/j.1741-3737.2002.00602.x

Prinzie, P., Stams, G. J. J., Deković, M., Reijntjes, A. H. A. i Belsky, J. (2009.), The Relations between Parents' Big Five Personality Factors and Parenting: A Meta-Analytic Review. Journal of Personality and Social Psychology, 97 (2): 351-362. doi:10.1037/a0015823

Rabin, A. I. (1965.), Motivation for Parenthood. Journal of Projective Techniques and Personality Assessment, 29 (4): 405-413. doi:10.1080/0091651 X.1965.10120230

Ragozin, A. S., Basham, R. B., Crnic, K. A., Greenberg, M. T. i Robinson, N. M. (1982.), Effects of Maternal Age on Parenting Role. Developmental Psychology, 18 (4): 627-634. doi:10.1037//0012-1649.18.4.627

Shulman, S. i Seiffge-Krenke, I. (2001.), Adolescent Romance: Between Experience and Relationships. Journal of Adolescence, 24 (3): 417-428. doi:10.1006/jado.2001.0403

Sigle-Rushton, W. (2005.), Young Fatherhood and Subsequent Disadvantage in the United Kingdom. Journal of Marriage and Family, 67 (3): 735-753. doi:10.1111/j.1741-3737.2005.00166.x

Snarey, J. i Clark, P. Y. (1998.), A Generative Drama: Scenes from a Father-Son Relationship. U: D. P. McAdams i E. de St. Aubin (ur.), Generative and Adult Development: How and Why We Care for the Next Generation (str. 45-74), Washington DC, APA Press.

Sollie, D. L. i Miller, B. C. (1980.), The Transition to Parenthood as a Critical Time for Building Family Strengths. U: N. Stinnett, B. Chesser, J. DeFrain i P. Knaub (ur.), Family Strengths: Positive Model of Family Life (str. 149-169), Lincoln, University of Nebraska Press.

Stryker, S. (1987.), Identity Theory: Development and Extensions. U: K. Yardley i T. Honess (ur.), Self and Identity: Psychosocial Perspective (str. 89-103), London, Wiley.

Terry, D. J., Mayocchi, L. i Hynes, G. J. (1996.), Depressive Symptomatology in New Mothers: A Stress and Coping Perspective. Journal of Abnormal Psychology, 105 (2): 220-231. doi:10.1037//0021-843X.105.2.220

Vaillant, G. E. (1997.), The Wisdom of the Ego, Cambridge, MA, Harvard University Press.

Vaz, R., Smolen, P. i Miller, C. (1983.), Adolescent Pregnancy: Involvement of the Male Partner. Journal of Adolescent Health Care, 4 (4): 246-250. doi:10.1016/S0197-0070(83)80005-9

Zeanah, C. H., Boris, N. W. i Larrieu, J. A. (1997.), Infant Development and Developmental Risk: A Review of the Past 10 Years. Journal of the American Academy of Child and Adolescent Psychiatry, 36 (2): 165-178. doi:10.1097/00004583-199702000-00007 
DRUŠ. ISTRAŽ. ZAGREB GOD. 20 (2011) BR. 4 (114),

STR. 1063-1083

LACKOVIĆ-GRGIN, K. DOŽIVLJAJ I PRAKSA...

\section{The Experience and Practice of Parenting in Different Periods of Life \\ Katica LACKOVIĆ-GRGIN \\ Zadar}

The motivation for parenting, or for the need, desire, and decision for having children, is influenced by biological, psychological, and social factors. The interaction of these factors determines the taking part and acceptance of parental roles and the quality of the relationship with children in different periods of life. The intention of this paper is to discuss some specific aspects of parenting with regard to the developmental characteristics of parents and children. The experience and practice of parenting in adolescence differs from those in adulthood. Young people lack many resources which enable prominence of parental roles and parental commitment. During earlier adulthood the social network encourages parenting which contributes to the increasing importance of maternal or paternal identity, influencing in turn the experience of parenting and the open forms of parental behavior. The experience and practice of parenting in middle adulthood is associated with the development of generativity, making the relationships of adult parents and their children more complex. Ambivalence appears in these relationships, especially when children have not achieved an anticipated normative status (completion of education, financial independence, marriage, etc.). In old age, which is dedicated to addressing the crisis of integrity versus despair, the actual experience of parenting is associated with the evaluation of its features during earlier periods of life. The outcomes of this evaluation, as well as the quality of current relationships, determine the behavior toward adult children and the satisfaction with parenting.

Keywords: stages of parenthood, motivation for parenting, parental behavior, parental identity, generativity, extension of parenting

\section{Elternschaft - erlebt und praktiziert in verschiedenen Lebensabschnitten}

\section{Katica LACKOVIĆ-GRGIN}

Zadar

Die Motivation zur Elternschaft bzw. Bedürfnis, Wunsch und Entschluss, eine Familie zu gründen, hängen von biologischen, psychologischen und sozialen Faktoren ab. Ihre Interaktion gibt den Ausschlag und bestimmt nicht nur, ob man sich zu diesem Schritt entschließt, sondern auch wie sich das Eltern-Kind-Verhältnis in den verschiedenen 
DRUŠ. ISTRAŽ. ZAGREB GOD. 20 (2011), BR. $4(114)$

STR. 1063-1083

LACKOVIĆ-GRGIN, K.: DOŽIVLJAJ I PRAKSA...
Lebensabschnitten gestaltet. Im vorliegenden Artikel sollen bestimmte Spezifika des Elterndaseins vor dem Hintergrund von Entwicklungsmerkmalen bei Eltern und Kindern untersucht werden. Elternschaft gestaltet sich in der Adoleszenz anders als im reifen Erwachsenenalter. Junge Eltern entbehren viele Ressourcen, die Nachdruck und Hingabe in der Elternrolle erst ermöglichen. Im jungen Erwachsenenalter wirkt das Netz sozialer Kontakte ermutigend auf junge Eltern und trägt bei zur Identitätsstiftung als Mutter bzw. Vater, was wiederum das Erleben der elterlichen Rolle und das elterliche Verhalten selbst beeinflusst. Eltern im reifen Erwachsenenalter werden in ihrer Einstellung durch eine sich entwickelnde Generativität beeinflusst, sodass das Eltern-Kind-Verhältnis komplexer wird. In diesem Verhältnis können sich zudem Ambivalenzen einstellen, zumal wenn Kinder einen bestimmten vorgesehenen normativen Status nicht erreichen (Schulabschluss, finanzielle Selbstständigkeit, Heirat u.a.). Im Alter, das eine späte Identitätskrise bringt, mit der man sich auseinandersetzen muss, um nicht der Verzweiflung anheimzufallen, verbindet sich Elternschaft mit einer Evaluierung ihrer selbst in der zurückliegenden Zeit. Je nachdem, wie man die eigene Rolle als Mutter oder Vater bewertet, und je nach der Qualität des aktuellen Eltern-KindVerhältnisses gestaltet sich auch die eigene Einstellung zu den nun erwachsenen Kindern und die Zufriedenheit mit sich selbst in der Rolle als Mutter oder Vater.

Schlüsselbegriffe: Phasen der Elternschaft, Motivation zur Elternschaft, elterliches Verhalten, Identität als Vater oder Mutter, Generativität, Extension der Elternschaft 